\title{
Tinjauan Implementasi Pembangunan Berkelanjutan: Pengelolaan Sampah Kota Kendari
}

Faturachman Alputra Sudirman ${ }^{1}$, Phradiansah ${ }^{2}$

fatur@uho.ac.id ${ }^{1}$,phradiansah11@gmail.com²

${ }^{1}$ Program Studi Ilmu Pemerintahan, FISIP, Universitas Halu Oleo, Kampus Hijau

Bumi Tridharma Anduonohu, Kendari, 93232, Indonesia

${ }^{2}$ Program Studi Manajemen, FISIP, Universitas Sembilanbelas November Kolaka, Jl. Pemuda, Kolaka, 93561, Indonesia

\begin{abstract}
Abstrak
Isu permasalahan pengelolaan sampah menjadi perhatian utama Pemerintah Daerah Kota Kendari untuk menjadi kota layak huni yaitu pembangunan Kota Kendari yang berkelanjutan. Penelitian ini membahas mengenai tantangan implementasi kebijakan pengelolaan sampah berbasis sustainable development di Kota Kendari. Salah satu tujuan pembangunan berkelanjutan dalam agenda 2030 adalah mengurangi dampak lingkungan perkotaan dengan indikator persentase sampah perkotaan yang tertangani. Tujuan penelitian ini untuk mengetahui implementasi kebijakan pengelolaan sampah dengan menggunakan konsep implementasi kebijakan oleh Edwards III dan mengaitkannya dengan konsep pembangunan berkelanjutan dan agenda 2030 Tujuan Pembangunan Berkelanjutan (SDGs). Penelitian ini menggunakan metode kualitatif, di mana data dikumpulkan melalui wawancara, dan dokumentasi, temuan dalam penelitian ini bahwa implementasi kebijakan pengelolaan sampah di Kota Kendari cukup baik pada aspek komunikasi, sumberdaya, disposisi, dan struktur birokrasi. Namun berbagai tantangan juga turut hadir pada setiap aspek implementasi kebijakan. Secara keseluruhan implementasi kebijakan pengelolaan sampah turut memperhatikan pembangunan berkelanjutan pada aspek ekonomi, sosial, dan lingkungan serta telah sesuai dengan upaya pencapaian SDGs Tujuan ke 11 di mana 73.30 persen sampah perkotaan telah tertangani.
\end{abstract}

Kata kunci: Implementasi, Kebijakan, Pemerintah, Sampah, SDGs

\begin{abstract}
Waste management issues is the primary concern of the Kendari City Government, considering to become a liveable city namely the sustainable development of Kendari City. This study discusses the challenges of implementing a waste management policy based sustainable development in Kendari City. One of the goals of sustainable development on the 2030 agenda is to reduce the impact of the urban environment with the percentage of municipal reliable waste handling indicators. The purpose of this study is to determine the implementation of waste management policies using the concept of policy implementation by Edwards III and to link it to the concept of sustainable development and the 2030 agenda of Sustainable Development Goals (SDGs). This study used a qualitative method, in which data was collected through interviews and documentation, the findings in this study that the implementation of waste management policies in Kendari City was quite excellent in the aspects of communication, resources, disposition, and bureaucratic structure. However, various challenges were also present in every aspect of policy implementation. Overall, the implementation of waste management policies also takes into account sustainable development in economic, social and environmental aspects and was by efforts to achieve SDGs Goal 11, where 73.30 per cent of urban waste has been handled.
\end{abstract}

Keywords: Implementation, Policy, Government, Waste, SDGs 


\section{Pendahuluan}

Isu mengenai masalah sampah tidak hanya menjadi isu nasional bahkan telah menjadi perhatian global, didorong oleh percepatan urbanisasi dan pertumbuhan populasi, World Bank (2018) merilis timbulan sampah tahunan global diperkirakan akan melonjak menjadi 3,4 miliar ton selama 30 tahun ke depan, naik dari 2,01 miliar ton pada 2016. Seluruh negara-negara di kawasan pun dituntut untuk bertindak mengatasi masalah sampah tersebut. Sampah plastik dianggap paling bermasalah jika tidak dikumpulkan dan dikelola dengan benar karena dampak jangka panjang yang ditimbulkan terhadap lingkungan. Pada 2016, dunia menghasilkan 242 juta ton limbah plastik, atau 12 persen dari semua limbah padat.(Kaza, Yao, BhadaTata, \& Woerden, 2018).

Sampah dan limbah telah menjadi permasalahan nasional di Indonesia. Masalah persampahan erat kaitannya dengan pertambahan penduduk, pertumbuhan ekonomi dan perubahan pola konsumsi masyarakat. Hal ini sejalan dengan UndangUndang Nomor 18 Tahun 2008 bahwa pertambahan jumlah sampah disebabkan oleh beberapa hal, antara lain karena pertambahan penduduk dan perubahan pola konsumsi masyarakat menimbulkan bertambahnya volume, jenis, dan karakteristik sampah yang semakin beragam.

Pada tahun 2018 jumlah penduduk Indonesia sudah mencapai 265,3 juta jiwa meningkat dibanding tahun 2000 yang sebesar 206,26 juta jiwa. Peningkatan juga dialami pada pertumbuhan ekonomi di mana kontribusi terbesar bersumber dari sektor manufaktur. Produk Domestik Bruto yang dihasilkan dari sektor ini sebesar 2.739,4 triliun di 2017, meningkat dari tahun 2000 yang hanya sebesar 385,5 triliun. (Badan Pusat Statistik, 2018). Pertumbuhan pesat di sektor industri juga merupakan imbas dari meningkatnya pendapatan rumah tangga dan semakin beragamnya pola serta jenis konsumsi masyarakat. Kondisi tersebut menimbulkan bertambahnya volume, beragamnya jenis, dan karakteristik sampah dan limbah. Menurut Kementerian Lingkungan Hidup dan Kehutanan (KLHK) pada tahun 2018 produksi sampah nasional mencapai sekitar 65,8 juta ton per tahunnya di mana 16 persennya adalah sampah plastik.(Republika.co.id, 2018).

Proyeksi penduduk Indonesia menunjukkan angka penduduk yang terus bertambah dan berimplikasi pada meningkatknya jumlah timbulan sampah. Regulasi dalam menangani permasalahan sampah dan limbah tertuang dalam Undang-Undang Nomor 18 tahun 2008 tentang Pengelolaan Sampah dan turunannya, serta UndangUndang Nomor 32 Tahun 2009 tentang Perlindungan dan Pengelolaan Lingkungan Hidup. Dalam Peraturan Presiden No. 97 tahun 2017 tentang Kebijakan dan Strategi Nasional Pengelolaan Sampah Rumah Tangga (SRT) dan sampah sejenis sampah rumah tangga (SSRT). Pemerintah menargetkan pengurangan sampah rumah tangga dan sampah sejenis sampah rumah tangga sebesar 30 persen dan penanganannya mencapai 70 persen sampai 2025. (Presiden Republik Indonesia, 2008, 2009, 2017).

Penanganan sampah ini sejalan dengan target Sustainable Development Goals (SDGs) pada tujuan ke 11.6 yaitu pada tahun 2030, mengurangi dampak lingkungan perkotaan per kapita yang merugikan, termasuk dengan memberi perhatian khusus pada kualitas udara, termasuk penanganan sampah kota yang diperjelas dalam indikator 11.6.1.(a) Persentase sampah perkotaan yang tertangani. Serta Tujuan ke 12.5, bahwa pada tahun 2030 setiap negara secara substansial mengurangi timbulan sampah melalui pencegahan, pengurangan, daur ulang, dan 
penggunaan kembali. Target SDGs dan Pepres tersebut merupakan salah satu upaya penanganan timbulan sampah khususnya di daerah perkotaan.

Permasalahan penyelenggaraan pengelolaan sampah juga terjadi di Kota Kendari. Pertumbuhan penduduk dan masifnya pembangunan kawasan permukiman terus berkembang, jumlah penduduk Kota Kendari pada tahun 2018 mencapai 359.371 jiwa, hal ini kemudian berdampak pada jumlah volume sampah yang terus meningkat. Bertambahnya jumlah penduduk di Kota Kendari mengakibatkan timbunan sampah perorang sebanyak $0.69 \mathrm{Kg} /$ hari atau 247.96 ton perhari, sumber sampah terbanyak berasal dari sejumlah pasar dan limbah rumah tangga.(BAPPEDA Kota Kendari, 2018).

Problematika dalam penyelenggaraan pengelolaan sampah di Kota Kendari, mendorong Pemerintah Daerah membuat sebuah kebijakan yang mengatur tentang pengelolaan sampah. Kebijakan yang tertuang dalam Peraturan Daerah Kota Kendari Nomor 4 tahun 2015 tentang pengelolaan sampah telah ditetapkan oleh Pemerintah Daerah Kota Kendari sejak tanggal 14 Juli 2015. Keberadaan Peraturan Daerah ini diharapkan mampu mengatasi kompleksitas permasalahan sampah yang terjadi di Kota Kendari (Walikota Kendari, 2015). Dinas Lingkungan Hidup dan Kehutanan Kota Kendari pun berupaya menjalankan kebijakan tersebut seperti menyediakan fasilitas baik unit kendaraan, TPS, TPA serta petugas kebersihan untuk mengatasi timbulan sampah yang terus meningkat. Sosialisasi mengenai pengelolaan sampah juga dilakukan di tingkat Kecamatan dan Kelurahan terkait waktu pembuangan sampah yang lebih disiplin. Namun upaya tersebut belum dianggap cukup mengingat masih banyak wilayah di Kota Kendari yang belum mendapatkan pelayanan secara rutin, termasuk dengan tingkat kesadaran masyarakat mengenai pengelolaan sampah.

Dalam konteks pembangunan berkelanjutan, pengelolaan sampah adalah kegiatan yang membentuk perlindungan lingkungan (Izvercian \& Ivascu, 2015). Saat ini, menurut sebuah studi (Ivascu, Cioca, \& Izvercian, 2014) sebagian besar organisasi mengaitkan pembangunan berkelanjutan dengan perlindungan lingkungan serta aktivitas yang terkait masyarakat. Perhatian terhadap lingkungan masih kuat di mana organisasi dan Kota mengembangkan kegiatan yang intensif ke arah ini. Pada awalnya, penekanan ditempatkan pada aktivitas pengumpulan sampah secara selektif (Brunner \& Rechberger, 2014) selanjutnya perhatian juga ditekankan pada pengelolaan dan daur ulang sampah. Semakin besar suatu wilayah maka tantangan pengelolaan sampah juga lebih kompleks (Lavee, 2007). Aktivitas manusia tidak bisa dihindari dalam menghasilkan sampah, dengan meningkatnya urbanisasi, maka keberlanjutan kota menjadi semakin penting (Zinkernagel, Evans, \& Neij, 2018).

Kota Kendari berupaya mewujudkan Visi dan Misi sebagai Kota Layak Huni (Liveble City) yaitu terlaksananya pembangunan kota Kendari yang berkelanjutan dengan mengurangi dampak negatif yang terjadi pada pelaksanaan pembangunan terkait dengan lingkungan. Sehingga aksi pengurangan sampah, dan pengelolaan sampah berkontribusi signifikan terhadap pencapaian pembangunan berkelanjutan. Berdasarkan uraian tersebut. Maka penelitian ini lebih lanjut membahas tiga hal: (1) pengelolaan sampah di Kota Kendari, (2) tantangan implementasi kebijakan pengelolaan sampah di Kota Kendari, (3) implementasi kebijakan pengelolaan sampah berbasis pembangunan berkelanjutan. 


\section{Tinjauan Pustaka}

\section{Implementasi Kebijakan}

Implementasi kebijakan menunjuk aktivitas menjalankan kebijakan dalam ranah senyatanya, baik yang dilakukan oleh organ pemerintah maupun para pihak yang telah ditentukan dalam kebijakan. Implementasi kebijakan pada dasarnya adalah cara atau langkah yang dilakukan agar sebuah kebijakan dapat mencapai tujuannya, Mazmanian dan Sabatier (1983) menyebut sebagai upaya melaksanakan keputusan. Implementasi kebijakan sendiri terdiri dari pihak implementor, dan kelompok sasaran. Implementor kebijakan adalah mereka yang secara resmi diakui sebagai individu/ lembaga yang bertanggung jawab atas pelaksanaan program di lapangan, sedangkan kelompok sasaran adalah menunjuk para pihak yang dijadikan sebagai objek kebijakan (Indiahono, 2009).

Van Meter dan Van Horn (1975), merumuskan proses implementasi sebagai "those actions by public or private individuals (or groups) that are directed at the achievement of objectives set forth in prior policy decisions". Definisi yang diuraikan tersebut menunjukan bahwa implementasi mengandung pengertian tindakan yang dilakukan individu atau pejabat maupun swasta yang diarahkan pada pencapaian tujuan yang ditetapkan sebelumnya. Ripley dan Franklin dalam Winarno (2008) memandang implementasi juga terkait yang terjadi setelah undang - undang ditetapkan yang memberikan otoritas program, kebijakan, keuntungan (benefit), atau suatu jenis keluaran yang nyata (tangible output). Secara fundamental istilah implementasi menggambarkan pada sejumlah kegiatan untuk mencapai tujuan-tujuan program dan hasil-hasil yang diinginkan seperti yang dimaksud oleh pejabat pemerintah. Implementasi mencakup tindakan-tindakan (tanpa tindakan-tindakan) oleh berbagai aktor, khususnya para birokrat, yang dimaksudkan untuk membuat program berjalan.

Edwards III (1980) berpendapat ada empat faktor atau variabel berpengaruh terhadap implementasi kebijakan yaitu 1). Komunikasi berkaitan dengan transmisi, kejelasan dan konsistensi. 2). Sumber daya berkaitan dengan staf serta keahlian yang dimiliki, informasi, wewenang, serta fasilitas-fasilitas yang diperlukan dalam implementasi kebijakan. 3) Disposisi terkait sikap pelaksana terhadap kebijakan. 4) Struktur birokrasi berhubungan dengan prosedur-prosedur kerja ukuran-ukuran dasar atau sering disebut Standard Operating Procedures (SOP) dan fragmentasi atau tanggung jawab kebijakan bidang tertentu. Empat faktor tersebut digunakan untuk menjelaskan sejauh mana implementasi kebijakan pengelolaan sampah di Kota Kendari serta tantangan yang dihadapi.

\section{Pembangunan Berkelanjutan (Sustainable Development)}

Selanjutnya konsep pembangunan berkelanjutan digunakan lebih lanjut untuk menganalisa implementasi kebijakan pengelolaan sampah di Kota Kendari yang memperhatikan aspek-aspek pembangunan berkelanjutan. Word Commission on Environment and Development (1987) mendefinisikan pembangunan berkelanjutan yaitu pembangunan yang memenuhi kebutuhan generasi saat ini tanpa mengorbankan pemenuhan kebutuhan generasi yang akan datang. Dispesifikan dalam Brundtland Report (WCED, 1987) dalam tiga aspek yaitu ekonomi, sosial dan lingkungan. (Tanguay, Rajaonson, Lefebvre, \& Lanoie, 2009). 
Pada perkembangannya, konsep pembangunan berkelanjutan dipopulerkan sebagai konsep yang didasarkan pada tiga dimensi atau pilar keberlanjutan yang seimbang yaitu pilar ekologi, sosial, dan ekonomi. Pembangunan berkelanjutan menyaratkan pencapaian pada : 1) Keberlanjutan ekologi yaitu melindungi kualitas lingkungan yang dibutuhkan untuk aktivitas ekonomi dan kualitas kehidupan (perlindungan lingkungan, mengurangi emisi polutan, rasionalitas penggunaan sumber daya, dan lain-lain), 2) Keberlanjutan Sosial terkait preservasi masyarakat dan identitas budaya menghormati keberagaman budaya, ras dan agama, preservasi nilainilai sosial, aturan, norma, perlindungan Hak Asasi Manusia dan lain-lain), dan 3) Keberlanjutan ekonomi memperhatikan aspek alam, sosial, dan manusia. Hubungan tiga pilar ini seimbang, interaksi tidak terpisah, dan saling berhubungan dalam kerangka keberlanjutan atau konsep yang dikenal Triple bottom line oleh John Elkington (1994) (Klarin, 2018).

Pada perkembangannya konsep pembangunan berkelanjutan direviu di tahun 2015 pada UN Conference on Sustainable Development di New York membahas Agenda 2030 untuk Pembangunan Berkelanjutan (The 2030 Agenda for Sustainable Development atau SDGs) dengan 17 Tujuan Pembangunan Milenium yang baru yang bertujuan untuk dicapai pada tahun 2030 menekankan arah pembangunan berkelanjutan yang berbasiskan hak asasi manusia dan kesetaraan untuk mendorong pembangunan sosial, ekonomi dan lingkungan hidup (United Nations General Assembly, 2015). Permasalahan sampah menjadi sorotan dalam SDGs pada tujuan ke 11.6 yang diperjelas dalam indikator 11.6.1.(a) Persentase sampah perkotaan yang tertangani. Indikator persentase sampah perkotaan yang tertangani adalah persentase jumlah sampah perkotaan yang ditangani dibandingkan dengan jumlah sampah perkotaan secara keseluruhan. Indikator ini digunakan untuk meningkatkan jumlah penanganan sampah perkotaan dalam mengurangi dampak lingkungan dan mendukung peningkatan kesehatan masyarakat dan kualitas lingkungan kota. (Badan Pusat Statistik, 2017).

Tabel 1. Matriks Relasi Implementasi Kebijakan Pengelolaan Sampah dengan SDGs

\begin{tabular}{|c|c|c|c|}
\hline $\begin{array}{c}\text { Implementasi } \\
\text { Kebijakan } \\
\text { Pengelolaan Sampah } \\
\text { di Kota Kendari }\end{array}$ & Tujuan Ke 11 & Target 11.6 & Indikator 11.6a \\
\hline $\begin{array}{l}\text { - Komunikasi } \\
\text { - Sumberdaya } \\
\text { - Disposisi } \\
\text { - Struktur Birokrasi }\end{array}$ & $\begin{array}{l}\text { Menjadikan kota dan } \\
\text { permukiman inklusif, } \\
\text { aman, tangguh } \\
\text { dan berkelanjutan }\end{array}$ & $\begin{array}{l}\text { Pada tahun } 2030 \text {, } \\
\text { mengurangi dampak } \\
\text { lingkungan perkotaan per } \\
\text { kapita yang merugikan, } \\
\text { termasuk dengan memberi } \\
\text { perhatian khusus pada } \\
\text { kualitas udara dan } \\
\text { penanganan sampah kota. }\end{array}$ & $\begin{array}{l}\text { Persentase sampah } \\
\text { perkotaan yang } \\
\text { tertangani. }\end{array}$ \\
\hline
\end{tabular}

Sumber: Diolah oleh penulis berdasarkan Dokumen Metada Data SDGs (Bappenas 2017) 
Tabel di atas menggambarkan bahwa secara langsung implementasi kebijakan pengelolaan sampah di Kota Kendari mendukung upaya pencapaian Program Pembangunan Berkelanjutan/SDGs pada tujuan ke 11 yaitu menjadikan kota dan permukiman inklusif, aman, tangguh, dan berkelanjutan dengan fokus pada target 11.6 yaitu pada tahun 2030 mengurangi dampak lingkungan perkotaan per kapita yang merugikan dengan memberikan perhatian khusus pada penanganan sampah kota. Target ini dapat diukur melalui indikator 11.6a yaitu persentase sampah perkotaan yang tertangani.

Adapun Undang-Undang No. 32 Tahun 2009 Tentang Perlindungan dan Pengelolaan Lingkungan Hidup mendefinisikan Pembangunan Berkelanjutan sebagai upaya sadar dan terencana yang memadukan aspek lingkungan hidup, sosial, dan ekonomi ke dalam strategi pembangunan, tujuannya menjamin keutuhan lingkungan hidup dan juga keselamatan, kemampuan, kesejahteraan, dan mutu hidup tidak hanya generasi masa kini, tapi juga generasi masa depan.

\section{Metode}

Penelitian ini menggunakan metode penelitian deskriptif dengan pendekatan kualitatif dengan lokasi penelitian di Kota Kendari. Sumber data yang digunakan adalah data primer dan data sekunder. Teknik pengumpulan data dilakukan dengan beberapa metode yaitu Pertama, wawancara mendalam dilakukan pada Kepala Bidang Persampahan Dinas Lingkungan Hidup dan Kehutanan Kota Kendari, Camat Poasia, dan Lurah Baruga Kota Kendari. Pemilihan informan ini terkait pertimbangan pemahaman mengenai implementasi kebijakan pengelolaan sampah di Kota Kendari. Kedua, dokumentasi yaitu pengumpulan terkait dokumen pemerintah, buku, jurnal, hasil studi akademik, dan artikel media massa. Adapun metode analisis data yang digunakan adalah analisis model interaktif yaitu dengan cara pengumpulan data, reduksi data, penyajian data, dan simpulan (Miles \& Huberman, 2007). Terkait dengan fokus penelitian adalah tantangan implementasi kebijakan pengelolaan sampah ditinjau pada aspek Komunikasi, Sumberdaya, Disposisi, dan Struktur Birokrasi. Sedangkan analisis implementasi kebijakan berbasis sustainable development diuraikan pada tiga aspek yaitu Ekonomi, Sosial, dan Lingkungan.

\section{Hasil dan Pembahasan}

Berdasarkan letak geografisnya, wilayah Kota Kendari terletak di bagian Tenggara Pulau Sulawesi. Luas wilayah daratan Kota Kendari 271,76 km2 atau 0,7 persen dari luas daratan Provinsi Sulawesi Tenggara. Penduduk Kota Kendari berdasarkan proyeksi penduduk tahun 2018 sebanyak 381.628 jiwa yang terdiri atas 192.621 jiwa penduduk laki-laki dan 189.007 jiwa penduduk perempuan. Dibandingkan dengan proyeksi jumlah penduduk tahun 2017, penduduk Kota Kendari mengalami pertumbuhan sebesar 2,94 persen dengan masing-masing persentase pertumbuhan penduduk laki-laki sebesar 2,88 persen dan penduduk perempuan sebesar 3,00 persen. Sementara itu besarnya angka rasio jenis kelamin tahun 2018 penduduk laki-laki terhadap penduduk perempuan sebesar 101,91. Kepadatan penduduk di Kota Kendari tahun 2018 mencapai 1.404 jiwa $/ \mathrm{km} 2$. (Badan Pusat Statistik Kota Kendari, 2019). 
Tabel 2. Data Pengelolaan Sampah Kota Kendari pada Tahun 2017-2018

\begin{tabular}{ccc}
\hline No & Uraian & Jumlah \\
\hline $\mathbf{1}$ & Jumlah penduduk & 356594 Jiwa \\
\hline $\mathbf{2}$ & Jumlah Timbulan sampah harian ibu kota & 229.46 Ton/hari \\
\hline $\mathbf{3}$ & Jumlah Sampah tidak terkelola & 10.29 Ton/hari \\
\hline $\mathbf{4}$ & Presentase yang terlayani (\%) & $73.30 \%$ \\
\hline & Sumber: & Kementerian Lingkungan Hidup dan Kehutanan, 2018)
\end{tabular}

Kepadatan penduduk memberikan implikasi pada volume timbunan sampah di Kota Kendari. Pada tahun 2013 misalnya, produksi sampah di Kota Kendari mencapai $270.803 \mathrm{~m} 3 /$ tahun, sedangkan volume sampah yang diangkut oleh Dinas Lingkungan Hidup dan Kehutanan Kota Kendari sebesar 110 m3/tahun, pihak lain termasuk perusahaan - perusahaan swasta dan masyarakat sekitar $89 \mathrm{~m} 3 /$ tahun, dan sisa yang belum terangkut sebesar $71.022 \mathrm{~m} 3 /$ tahun, ditangani oleh masyarakat baik secara individual maupun kelompok dengan cara memposting, ditanam, dikumpulkan oleh pemulung untuk dijual dan lain - lain. Pada periode 2017-2018 jumlah timbulan sampah harian ibu kota 229.46 ton/hari dan jumlah sampah yang tidak terkelola 10.29 Ton/hari, adapun jumlah persentase yang terlayani sebesar $73.30 \%$.

\section{Pengelolaan Sampah di Kota Kendari}

Pengelolaan sampah di Kota Kendari berdasarkan Pasal 19 Peraturan Daerah No 4 Tahun 2015 bahwa penanganan sampah rumah tangga dan sampah sejenis sampah rumah tangga, meliputi pemilahan, pengumpulan, pengangkutan, pengolahan, dan pemrosesan akhir sampah.

Pemilahan: Kegiatan pemilahan sampah dilakukan dalam bentuk pengelompokan dan pemisahan sampah sesuai dengan jenis, jumlah dan/atau sifat sampah. Pada proses pewadahan ini ada beberapa kendala yang sering ditemui yaitu ketersediaan tempat penampungan sampah harian yang wajib disediakan oleh pemilik bangunan (rumah) di pekarangan rumah. Pemerintah Daerah melalui Dinas Lingkungan hidup dan Kehutanan Kota Kendari telah menyediakan sarana pewadahan sampah di mana Tempat Penampungan Sampah (TPS) yang telah tersedia sebanyak 1062 unit, Kontainer 5 unit, TPS Non Permanen 188 unit, Sedangkan yang tidak memiliki TPS sebanyak 107 unit.

Pengumpulan: Pengumpulan sampah dilakukan dalam bentuk pengambilan dan pemindahan sampah dari sumber sampah ke TPS atau Tempat Pengolahan Sampah Terpadu (TPST) oleh Motor Sampah (sampah Lingkungan) ke TPS, dari Gerobak (Sampah Lingkungan) ke TPS. Pengangkutan: Penanganan pengangkutan sampah dilaksanakan oleh DLHK Kota Kendari, dan pihak swasata lainnya. Per tahunnya sekitar $110.78 \mathrm{~m} 3$ yang diangkut oleh Dinas Lingkungan Hidup dan Kehutanan Kota Kendari, dan sekitar 89 m3 diangkut oleh pihak swasta/lainnya jadi sekitar $199.781 \mathrm{~m} 3$ per tahun yang diangkut ke Tempat Pemrosesan Akhir (TPA). Pelayanan Pengangkutan Sampah dilaksanakan baik melalui Pelayanan Langsung yaitu Pengangkutan sampah dilaksanakan secara dor to dor oleh truck Dinas Lingkungan Hidup dan langsung dibuang ke TPAS Puuwatu, maupun Pelayanan 
Tidak Langsung yaitu pengangkutan dilaksanakan dari tempat penumpukan sementara (TPS) ke tempat TPAS Puuwatu.

Pengolahan: Proses pengolahan tidak hanya dilakukan di TPA namun juga dilakukan di TPST. Program pengolahan di TPST seperti pembuatan kompos dan daur ulang namun pelaksanaan pengolahan di TPST belum sepenuhnya terlaksana dengan baik disebabkan komitmen pengelola dan kemampuan modal serta skill SDM yang terbatas. Terdapat beberapa TPST di Kota Kendari yang terus beroperasi seperti di TPST Lahundape yang menghasilkan kompos, dan sampah daur ulang. Juga TPST Alfaisin yang mendaur ulang sampah menjadi kreasi (bunga, baju, dll) yang bernilai ekonomis. Pemrosesan Akhir: Pemrosesan akhir sampah dilakukan dalam bentuk pengembalian sampah dan/atau residu hasil pengolahan sebelumnya ke media lingkungan secara aman. Pemrosesan akhir sampah dilakukan oleh Pemerintah Daerah dengan menggunakan metode lahan urug terkendali metode lahan urug saniter dan teknologi ramah lingkungan. TPAS terletak di wilayah administrasi Kelurahan Puuwatu, Kota kendari dan memiliki luas 17,46 Ha yang pengadaan lahannya bertambah secara bertahap yakni tahun 2002 sebanyak 12,46 Ha dan pada tahun 2013 bertambah sebanyak 5 Ha yang dibiayai oleh Anggaran Pemerintah Daerah Kota Kendari dan diperkirakan dapat beroperasi minimal 20 tahun. TPAS ini mulai beroperasi pada tahun 2002 secara Open Dumping sampai 2007 dan terus dikembangkan pada tahun 2008 operasional TPAS berubah menjadi Control Landfill, di mana sampah yang datang setiap hari diratakan dan dipadatkan dengan alat berat. Sampah dipadatkan menjadi sebuah sel, kemudian sampah yang sudah dipadatkan tersebut dilapisi dengan tanah setiap lima atau seminggu sekali. Hal ini dilakukan untuk mengurangi bau, mengurangi perkembangbiakan lalat, dan mengurangi keluarnya gas metan. Selain itu, dibuat juga saluran drainase untuk mengendalikan aliran air hujan, saluran pengumpul air lindi (leachate) dan instalasi pengolahannya, pos pengendalian operasional, dan fasilitas pengendalian gas metan.

\section{Tantangan Implementasi Kebijakan Pengelolaan Sampah di Kota Kendari}

Implementasi kebijakan pada prinsipnya merupakan cara agar suatu kebijakan dapat mencapai tujuannya. Edward III berpandangan bahwa implementasi kebijakan dipengaruhi oleh empat variabel yaitu pada aspek komunikasi, sumberdaya, disposisi, dan struktur birokrasi. Empat aspek tersebut selanjutnya akan diuraikan untuk menganalisa sejauh mana keberhasilan serta tantangan implementasi kebijakan pengelolaan sampah di Kota Kendari.

\subsection{Komunikasi}

Pelaksanaan kebijakan penyelenggaraan pengelolaan sampah di Kota Kendari, Dinas Lingkungan Hidup merujuk pada Peraturan Daerah No 4 Tahun 2015 yang menjadi acuan dasar dalam kegiatan pengelolaan sampah baik pengurangan maupun penanganan. Dalam aspek komunikasi proses transisi terkait perintah atau instruksi-instruksi, baik dari petugas dinas kepada sesama petugas sudah tersampaikan dengan jelas berdasarkan Peraturan Daerah tersebut. Selain itu himbauan berupa sosialisasi kepada masyarakat dilakukan melalui pemasangan media informasi, serta pemberitahuan secara langsung di tingkat Kelurahan mengenai jadwal pembuangan sampah sejak pukul 06.00 pagi sampai 18.00 sebagai upaya untuk meningkatkan pemahaman warga mengenai pengelolaan sampah di Kota Kendari. Hal ini seperti yang diungkapkan Prayitno Kepala Bidang Persampahan DLHK Kota 
Kendari, "Media informasi sudah dipasang sebagai bentuk sosialisasi bagi masyarakat untuk membuang sampah pada tempat dan sesuai waktu yang ditetapkan dan hasilnya di beberapa tempat mereka sudah mulai membuang dengan benar dan sesuai waktu" (Prayitno,2018).

Peraturan Daerah Kota Kendari No. 4 Tahun 2015 pada BAB V mengatur mengenai hak, kewajiban dan larangan. Salah satu hak masyarakat diatur ialah hak memperoleh informasi yang benar, akurat dan tepat waktu mengenai penyelenggaraan pengelolaan sampah. Namun terkait dengan komunikasi kepada masyarakat. Riset dari BAPPEDA Kota Kendari pada tahun 2018 bahwa menemukan hanya 37 persen masyarakat yang pernah mendapatkan informasi/sosialisasi mengenai penyelenggaraan pengelolaan sampah hal ini disebabkan kurang intensifnya sosialisasi dari pemerintah karena keterbatasan personil petugas kebersihan. Hal ini perlu menjadi perhatian bahwa pada aspek komunikasi penyampaian informasi ataupun sosialisasi kepada masyarakat perlu lebih gencar dilakukan sebagai target sasaran (target group) agar mengurangi distorsi implementasi.

\subsection{Sumberdaya}

Ketersediaan sumberdaya menjadi unsur pendukung dalam implementasi kebijakan pengelolaan sampah di Kota Kendari. DLH Kota Kendari sampai 2018 telah menyediakan fasilitas kegiatan pengelolaan persampahan. Namun, ada beberapa hal yang menjadi tantangan dalam Sumberdaya ini yakni ketersediaan jumlah petugas yang masih kurang. DLHK Kota Kendari memiliki salah satu tugas dalam penyelenggaraan sampah di Kota Kendari yaitu pada kegiatan pengangkutan dan pengolahan sampah dan menjadi tanggung jawab langsung dari Bidang Persampahan. Jumlah personil di Dinas Lingkungan Hidup khususnya di bagian angkutan sampah masih perlu adanya tambahan, tentu saja hal ini didasarkan pada masih ada wilayah kerja yang belum tertangani secara rutin dan maksimal.

Tantangan yang lain adalah ketersediaan sarana dan prasarana. Jumlah dan kualitas sarana prasarana pengelolaan sampah di Kota Kendari dinilai masih belum sesuai dari apa yang dibutuhkan di lapangan. Sejak 2014 jumlah kendaraan sebanyak 37 unit, rencana penambahan empat unit. Pada tahun 2015 ditambah enam unit yaitu dua Arm roll, dan empat dump truck. Namun, dalam hal pengangkutan misalnya, dibutuhkan jumlah truk pengangkut sampah yang lebih banyak lagi dan juga kualitas yang baik. Jumlah truk serta petugasnya masih kurang apabila dibandingkan dengan luasnya cakupan wilayah kota Kendari yang harus ditangani. DLHK Kota Kendari baru menangani sekitar hampir 80 persen dari 247.96 per ton timbunan sampah, masih ada sekitar 30 persen yang belum tertangani utamanya di sudut-sudut kota, ini disebabkan akses kendaraan tidak bisa masuk kewilayah wilayah yang sempit, sehingga timbunan sampah yang signifikan belum bisa ditangani di semua wilayah, meskipun demikian pelayanan dilakukan secara rutin dan temporer.

Pemerintah Daerah juga telah membangun Tempat Penampungan Sampah (TPS). Jumlah TPS yang sebelumnya dimiliki 1300 dan tersisa 1036 disebabkan kondisi TPS yang sudah lama dan rusak, keterbatasan lahan pembangunan TPS, serta TPS yang dibongkar oleh pemilik tanah. Selain itu pemerintah juga telah menyediakan TPST yang berfungsi untuk mengurangi timbunan sampah yang dibawa ke TPA dan diharapkan ada pemilahan dan pengolahan sampah yang bernilai 
ekonomi seperti daur ulang untuk kerajinan yang telah dibangun oleh Tata Kota melalui Direktorat PeningkatannLingkungan Perkotaan PU. TPST juga diprogramkan di Kompleks Perumahan. "Ada beberapa TPST yang beroperasi seperti di TPST labundape yang menghasilkan kompos, dan sampah daur ulang. Juga TPST Alfaisin yang mendaur ulang sampah menjadi bahan kreasi dan bernilai ekonomis seperti kreasi bunga, baju dan lain-lain” (Prayitno, 2018).

Selain itu keberadaan Bank Sampah di Kota Kendari sebagai upaya pengolahan sampah agar mengurangi jumlah timbunan sampah yang dimuat ke TPA. Keberadaan Bank Sampah dianggap mampu memberikan pemasukan tambahan dari hasil olahan sampah yang bernilai ekonomis seperti keberadaan Bank Sampah Puuwatu. Pembinaan yang dilakukan pun secara mandiri langsung oleh pengurus Bank Sampah dengan membawa sampah setiap sebulan sekali, dipilah lalu diproses secara bersama-sama. Kerjasama yang dilakukan oleh Badan Lingkungan Hidup, Kelurahan, dan beberapa instansi lainnya. Namun yang menarik pada aspek SDM ini adalah keberadaan kelompok yang tidak terorganisasi yang ikut serta dalam pengelolaan sampah yaitu keberadaan kelompok pemulung. Hasil pengumpulan sampah, mereka bawa ke lapak-lapak untuk dijual dan mampu mengurangi sampah yang di bawah ke TPA seperti yang diutarakan oleh Prayitno (Kabid Persampahan DLHK Kota Kendari), "Sekarang DLHK sedang mengoperasikan Bank Sampah Induk, sudah ada kantornya, kita ingin nantinya berbentuk koperasi serta ada Kelompok. Swadaya Masyarakatnya (KSM), buruh sampab bisa memenubi kebutuban pokok sebari-hari, jika belum punya uang mereka bisa ganti dengan hasil pemulungannya" (Prayitno, 9 Agustus 2018).

\subsection{Sikap Pelaksana (Disposisi)}

Disposisi atau sikap pelaksana kebijakan dalam melaksanakan kebijakan Peraturan Daerah Nomor 4 Tahun 2015 Tentang Pengelolaan Sampah di Kota Kendari dapat dilihat melalui tingkat kepatuhan pelaksana kebijakan. Jika pelaksanaan ingin efektif dan efisien, maka para pelaksana tidak hanya mengetahui apa yang akan dilakukan tetapi juga harus memiliki kemampuan untuk melaksanakannya. Para pelaksana implementasi kebijakan yang akan melakukan tugasnya diharapkan memiliki keinginan untuk dapat bekerja dengan patuh dalam pelaksanaan kebijakan implementasi tersebut. Komitmen yang tinggi dari pelaksana kebijakan akan membuat aparatur selalu antusias dalam melaksanakan tugas, wewenang, fungsi, dan tanggung jawab melalui pemahaman tentang tugas-tugas mengenai pengelolahan sampah yang akhirnya dapat menjalankan implementasi kebijakan Peraturan Daerah Nomor 4 Tahun 2015 Tentang Pengelolaan Sampah di Kota Kendari dengan baik.

Berdasarkan hasil wawancara mengenai komitmen yang telah dilakukan oleh Dinas Lingkungan Hidup dan Kehutanan Kota Kendari telah dilaksanakan sesuai dengan tujuan, pokok dan fungsi DLHK dalam pelaksanaan implementasi kebijakan Peraturan Daerah Nomor 4 Tahun 2015 Tentang Pengelolaan Sampah di Kota Kendari. Sehingga pemahaman mengenai Perda No 4 Tahun 2015 sangat penting dalam pelaksanaan kebijakan pengelolaan sampah seperti yang diungkapkan oleh kepala bidang persampahan DLHK Kota Kendari. "DLHK berkomitmen dalam mewujudkan pelayanan prima dalam penanganan sampah di Kota Kendari dan berpedoman kepada peraturan peraturan yang ada. Kalau mengenai perda untuk aparat kita khususnya di Lingkungan Hidup paham di atas 80 persen" (Prayitno, 2018). 
Salah satu ketegasan komitmen DLHK ialah penindakan kepada pemilik bangunan yang tidak melaksanakan ketentuan yang ditetapkan dalam Perda mengenai pengelolaan sampah yang akan ditegur langsung dan dikenai sanksi administratif seperti penahanan izin persuratan. Komitmen yang lain juga ialah Pembinaan Pengelolaan Sampah oleh DLHK yaitu pembinaan sampah berbasis 3R (Reduce, Reuse, Recycle) yang melibatkan dasawisma, RT/RW dan anak-anak sekolah sebagai bentuk sosialisasi pembinaan penglelolaan sampah.

\subsection{Struktur Birokrasi}

Struktur organisasi bertugas melaksanakan kebijakan dan memiliki pengaruh besar terhadap pelaksanaan kebijakan, di dalam struktur birokrasi terdapat dua hal penting yang dapat mempengaruhinya salah satunya Standar Operasi Prosedur atau SOP. SOP ini merupakan pedoman untuk para pelaksana kebijakan dalam bertindak atau menjalankan tugasnya. Selain SOP yang mempengaruhi struktur birokrasi adalah fragmentasi yang berasal dari luar organisasi. Standard Operational Procedures (SOP) dalam pelaksanaan implementasi kebijakan Pengelolaan Sampah di Kota Kendari sangat diperlukan, hal ini bertujuan agar dalam pelaksanaan implementasi kebijakan tersebut tidak keluar dari jalur yang telah ditentukan sehingga sesuai dengan peraturan yang telah ditentukan dan yang berlaku.

Struktur birokrasi di DLHK Kota Kendari dilaksanakan dengan baik dan benar sesuai dengan SOP dan tanggung jawab pelaksana. Namun beberapa kendala pada struktur birokrasi dalam implementasi kebijakan pengelolaan sampah adalah belum terlaksananya operasi yustisi seperti pemberian sanksi ataupun denda terhadap masyarakat yang membuang sampah tidak pada tempatnya dan waktu yang telah ditentukan. Sehingga, koordinasi dengan sesama lembaga dalam pengelolaan implementasi kebijakan pengelolaan sampah kota Kendari perlu dilakukan Dinas atau OPD terkait seperti Dinas Lingkungan Hidup dan Kehutanan Kota Kendari, dan SATPOL PP sebagai penindak dan pelaksana berlangsungnya peraturan terkait penindakan kepada pelanggar kebijakan.

\section{Implementasi Kebijakan Pengelolaan Sampah berbasis Pembangunan Berkelanjutan}

Pembangunan berkelanjutan mempertimbangkan perspektif ekonomi, sosial, dan lingkungan. Dalam mencapai pembangunan berkelanjutan dari perspektif ekonomi, maka dipertimbangkan cara untuk memajukan ekonomi dalam jangka panjang, tanpa menghabiskan modal alam. Kebijakan Pengelolaan sampah di Kota Kendari pun memperhatikan aspek ekonomi dalam pembangunan berkelanjutan.

Keberadaan Bank Sampah di Kota Kendari tidak hanya sebagai upaya mengurangi jumlah timbunan sampah yang dimuat ke TPA. Namun, keberadaan Bank Sampah juga membantu perekonomian masyarakat di mana hasil penjualan sampah disimpan dalam bentuk tabungan di bank sampah, masyarakat menyetor sampah kemudian ditimbang dan dihitung nilai ekonomisnya, nilai tersebut menjadi saldo di bank. Kegiatan tersebut diinisiasi dalam kerjasama antara pemerintah Kota Kendari dan program CSR pegadaian (Persero) di bawah program The Gade Clean and Gold (memilah sampah menabung emas).(Panjikendari.com, 2019; Sultrakini.com, 2018) 
Pada aspek sosial pemahaman lembaga-lembaga yang bertanggung jawab dalam kebijakan pengelolaan sampah juga baik, selain itu kesadaran dan partisipasi masyarakat dalam kebijakan pengelolaan sampah dalam hal pemeliharaan kebersihan lingkungan dan penyediaan penampungan sampah harian yang dihasilkan juga cukup baik. Hasil riset dari BAPPEDA Kota Kendari pada tahun 2018 terkait tingkat pemeliharaan kebersihan lingkungan oleh masyarakat Kota Kendari diketahui bahwa 85 persen masyarakat kota Kendari peduli dengan kebersihan lingkungan. Adapun mengenai kewajiban menyediakan tempat penampungan sampah harian sebanyak 63 persen masyarakat telah menyediakan tempat penampungan sampah harian.(BAPPEDA Kota Kendari, 2018)

Pada aspek lingkungan, keberlanjutan ekologis/lingkungan menjadi dasar bagi implementasi kebijakan pengelolaan sampah di Kota Kendari. Pemanfaatan Gas Metan di TPAS yang dimanfaatkan sebagai flaring, dapur dan operasional energi listrik TPAS sehari- hari dengan daya 5000 Watt. Pemanfaatan LFG TPAS terus ditingkatkan dan telah mampu memberdayakan $120 \mathrm{KK}$ baik untuk dapur dan penerangan listrik dengan kapasitas mesin 40000 Watt. Dan pada tahun 2013 pengembangan pemanfaatan gas metan di pasar PKL sebanyak 21 tungku dengan daya listrik yang dihasilkan sebesar 7000 Watt.

Berdasarkan uraian di atas maka diketahui bahwa implementasi kebijakan pengelolaan sampah di Kota Kendari yang ditinjau pada aspek komunikasi, sumberdaya, disposisi, dan struktur birokrasi telah memperhatikan aspek-aspek sustainable development yaitu perhatian pada ekonomi, sosial, dan lingkungan. Implementasi kebijakan pengelolaan sampah di Kota Kendari juga secara langsung berkonstribusi pada upaya pencapaian Tujuan Pembangunan Berkelanjutan/Sustainable Development Goals (SDGs) 2020, di mana DLHK Kota Kendari telah menangani sampah perkotaan 73.30 persen dari 247.96 per ton timbunan sampah di Kota Kendari, Hal ini kemudian selaras dengan pencapaian tujuan ke 11 SDGs yaitu menjadikan kota dan pemukiman inklusif, aman, tangguh dan berkelanjutan dengan target pada tahun 2030 salah satunya ialah mengurangi dampak lingkungan perkotaan per kapita yang merugikan, dengan indikator persentase sampah perkotaan yang tertangani.

\section{Kesimpulan}

Implementasi kebijakan pengelolaan sampah di Kota Kendari masih menghadapi tantangan di masing-masing aspek, pada aspek komunikasi, penyampaian komunikasi seperti instruksi dinas ke petugas mengenai pengelolaan sampah tersampaikan dengan jelas, serta telah ada sosialisasi melalui papan informasi sebagai bentuk komunikasi DLHK Kota Kendari bagi masyarakat. Namun tantangannya adalah rendahnya tingkat pengetahuan masyarakat di mana hanya 37 persen yang pernah mendapatkan informasi/sosialisasi mengenai penyelenggaraan pengelolaan sampah. Pada aspek sumberdaya telah tersedia sarana prasarana dan SDM yang mampu mengurangi jumlah timbunan sampah yang di bawah ke TPA. Namun tantangan yang dihadapi ialah masih ada daerah atau wilayah yang belum terlayani secara periodik karena keterbatasan armada dan sumberdaya manusia. Sumberdaya manusia berupa petugas pengangkutan sampah milik pemerintah (petugas harian lapangan) dinilai masih kurang apabila dibandingkan dengan luasnya wilayah yang harus dijangkau oleh petugas pengangkut. Pada aspek struktur birokrasi 
di DLHK kota kendari dilaksanakan dengan baik dan benar sesuai dengan SOP dan tanggung jawab pelaksana. Namun, belum ada koordinasi antar instansi untuk pembentukan tim yustisi serta penegakan sanksi denda atau pidana.

Namun terlepas dari semua itu implementasi kebijakan pengelolaan sampah telah memperhatikan aspek-aspek pembangunan berkelanjutan yaitu ekonomi di mana keberadaan Bank Sampah tidak hanya mampu mengurangi jumlah timbunan sampah namun juga telah membantu perekonomian masyarakat. Pada aspek sosial pemahaman, kesadaran, serta partisipasi masyarakat dalam implementasi kebijakan pengelolaan sampah juga cukup baik seperti penyediaan tempat penampungan sampah harian. Dan pada aspek lingkungan keberadaan TPAS telah dikembangkan pada pemanfaatan gas metan sebagai operasional energi listrik. Hal ini pun secara langsung telah mendorong upaya pencapaian SDGs pada tujuan ke 11 dengan indikator $73.30 \%$ persen sampah di Kota Kendari telah tertangani.

\section{Referensi}

Badan Perencanaan Pembangunan Daeah (BAPPEDA) Kota Kendari. (2018). Implementasi Kebijakan PERDA No. 4 Tahun 2015 Tentang Persampahan. Kendari.

Badan Pusat Statistik. (2017). Indikator Pembangunan Berkelanjutan 2017: Kemiskinan , Energi, dan Lingkungan. Badan Pusat Statistik.

Badan Pusat Statistik. (2018). Statistik Lingkungan Hidup Indonesia 2018 (Subdirektorat Statistik Lingkungan Hidup, Ed.). Badan Pusat Statistik.

Badan Pusat Statistik Kota Kendari. (2019). Kota Kendari dalam Angka 2019. Kendari: BPS Kota Kendari.

Brunner, P. H., \& Rechberger, H. (2014). Waste to energy - key element for sustainable waste management. Waste Management. https://doi.org/10.1016/j.wasman.2014.02.003

Edwards III, G. C. (1980). Implementing Public Policy. Washington D.C: Congressional Quarterly Press.

Indiahono, D. (2009). Kebijakan Publik Berbasis Dynamic Policy Analysis. Yogyakarta: Gava Media.

Ivascu, L., Cioca, L. I., \& Izvercian, M. (2014). Investigating the relationship between risk management and sustainable development management within the organizations. 11th International Conference on Innovation and Management, 1353-1361. Finlanda.

Izvercian, M., \& Ivascu, L. (2015). Waste management in the context of sustainable development: Case study in Romania. 26(15), 717-721. https://doi.org/10.1016/S2212-5671(15)00825-4

Kaza, S., Yao, L., Bhada-Tata, P., \& Woerden, F. Van. (2018). What a Waste 2.0 : A Global Snapshot of Solid Waste Management to 2050. Retrieved from https://openknowledge.worldbank.org/handle/10986/30317

Kementerian Lingkungan Hidup dan Kehutanan. (2018). Data Umum Sistem Informasi Pengelolaan Sampah Nasional. Retrieved from http:/ sipsn.menlhk.go.id/?q=3a-data-umum\&page $=7$

Kementerian Perencanaan Pembangunan Nasional/Badan Perencanaan Pembangunan Nasional (BAPPENAS). (2017). Meta Indikator Tujuan Pembangunan Berkelanjutan (TBP)/Sustainable Development Goals 
(SDGs) Indonesia. Jakarta: Kementerian Perencanaan Pembangunan Nasional/Badan Perencanaan Pembangunan Nasional (BAPPENAS).

Klarin, T. (2018). The Concept of Sustainable Development: From its Beginning to the Contemporary Issues. Zagreb International Review of Economics \& Business, 21(1), 67-94. https://doi.org/10.2478/zireb-2018-0005

Lavee, D. (2007). Is Municipal Solid Waste Recycling Economically Efficient? (August), 926- 943. https://doi.org/10.1007/s00267-007-9000-7

Mazmanian, D., \& Sabatier, P. A. (1983). Implementation and Public Policy. Glenview, III: Scott, Foresman, and Company.

Miles, M. B., \& Huberman, M. A. (2007). Qualitative Data Analysis (terjemahan). Jakarta: UI Press.

Panjikendari.com. (2019). Pemkot Kendari Punya Program Memilah Sampah Menabung Emas. Retrieved November 22, 2019, from Panjikendari.com website: https://panjikendari.com/pemkot-kendari-punya-programmemilah-sampah-menabung-emas/

Presiden Republik Indonesia. (2008). Undang-Undang Republik Indonesia Nomor 18 Tahun 2008 tentang Pengelolaan Sampah. Retrieved December 2, 2019, from Jaringan Dokumentasi dan Informasi Hukum (JDIH) Badan Pemeriksa Keuangan (BPK) RI website: https://peraturan.bpk.go.id/Home/Details/39067/uu-no-18-tahun-2008

Presiden Republik Indonesia. (2009). Undang-Undang Nomor 32 Tahun 2009 tentang Perlindungan dan Pengelolaan Lingkungan Hidup. Retrieved December 2, 2019, from Jaringan Dokumentasi dan Informasi Hukum (JDIH) Badan Pemeriks Keuangan (BPK) RI website: https://peraturan.bpk.go.id/Home/Details/38771/uu-no-32-tahun-2009

Presiden Republik Indonesia. (2017). Peraturan Presiden No. 97 Tahun 2017 tentang Kebijakan dan Strategi Nasional Pengelolaan Sampah Rumah Tangga (SRT) dan Sampah Sejenis Sampah rumah tangga (SSRT). Retrieved December 2, 2019, from Jaringan Dokumentasi dan Informasi Hukum (JDIH) Badan Pemeriksa Keuangan (BPK) RI website: https://peraturan.bpk.go.id/Home/Details/73225/perpres-no-97-tahun2017

Republika.co.id. (2018). KLHK_ Produksi Sampah Nasional 65,8 Juta Ton per Tahun_Republika Online Mobile. Retrieved September 14, 2019, from republika.co.id website: https://www.republika.co.id/amp/p7abz3284

Sultrakini.com. (2018). Kampung Salo Kini Punya Bank Sampah - SultraKini. Retrieved November 22, 2019, from Sultrakini.com website: https://sultrakini.com/berita/kampung-salo-kini-punya-bank-sampah

Tanguay, G. A., Rajaonson, J., Lefebvre, J., \& Lanoie, P. (2009). Measuring the Sustainability of Cities: A Survey-Based Analysis of the Use of Local Indicators. CIRANO - Scientific Publications No. 2009s-02. https://doi.org/http://dx.doi.org/10.2139/ssrn.1336649

United Nations General Assembly. (2015). Transforming our world: the 2030 Agenda for Sustainable Development. Resolution adopted by the General Assembly on 25 September 2015. Retrieved from https://www.un.org/ga/search/view_doc.asp?symbol=A/RES/70/1\&Lan $\mathrm{g}=\mathrm{E}$ 
Van Meter, D. S., \& Van Horn, C. E. (1975). Administration \& Society. https://doi.org/10.1177/009539977500600404

Walikota Kendari. (2015). Peraturan Daerah Kota Kendari Nomor 4 Tahun 2015 Tentang Pengelolaan Sampah. Retrieved December 2, 2019, from Jaringan Dokumentasi dan Informasi Hukum (JDIH) Badan Pemeriksa Keuangan (BPK https://peraturan.bpk.go.id/Home/Details/14626/perda-kota-kendari-no4-tahun-2015

Winarno, B. (2008). Kebijakan Publik: Teori dan Proses. Jakarta: PT Buku Kita.

World Bank. (2018). Global Waste to Grow by 70 Percent by 2050 Unless Urgent Action is Taken_ World Bank Report. Retrieved September 9, 2019, from worldbank.org website:

https://www.worldbank.org/en/news/pressrelease/2018/09/20/global-waste-to-grow-by-70-percent-by-2050-unlessurgent-action-is-taken-world-bank-report

Zinkernagel, R., Evans, J., \& Neij, L. (2018). Applying the SDGs to Cities : Business as Usual or a New Dawn? MDPI, Sustainability, 10, 1-18. https://doi.org/10.3390/su10093201

\section{Wawancara}

Prayitno. Kantor DLHK Kota Kendari, 9 Agustus 2018 